\title{
ROLE OF COLOR TO SUPPORT THE ACHIEVEMENT OF RELAXATION IN BUSSINES HOTEL (CASE STUDIES OF BUSINESS HOTEL IN SEMARANG)
}

\author{
Adel Issa Elsosan*), Edward E. Pandelaki, Titin Woro Murtini \\ Program Studi Magister Teknik Arsitektur, Fakultas Teknik, Universitas Diponegoro, \\ Jl. Hayam Wuruk 5, Kampus Undip Pleburan, Semarang, Indonesia
}

\begin{abstract}
Abstrak
Semarang sebagai pusat bisnis dan pariwisata di Jawa Tengah memberikan kesempatan bagi investor untuk berinvestasi di Semarang. Akhir-akhir ini bisnis perhotelan di Kota Semarang menunjukkan prospek cerah. Hal ini dapat dilihat dari meningkatnya jumlah wisatawan yang menginap di hotel. Salah satu alasannya adalah banyak kegiatan seperti pertemuan yang diselenggarakan oleh instansi pemerintah, baik lokal maupun nasional, yang diselenggarakan di kota Semarang. Berdasarkan hasil survei awal, sebagian besar hotel di Semarang masih minim fasilitas dan tidak berlaku pentingnya pelaksanaan warna bagi pengunjung. Studi tentang peran warna untuk mencapai relaksasi ini penting karena jika relaksasi mencapai sehingga manusia dapat membuat lebih konsentrasi dan merasa menyegarkan. Tujuan dari penelitian ini adalah: Studi tentang bagaimana warna mempengaruhi dalam penciptaan relaksasi di hotel bisnis di Semarang. Sampel penelitian diarahkan ke hotel menggunakan warna dingin dan hotel warna hangat di Semarang. Metode analisis yang digunakan adalah analisis deskriptif. Berdasarkan hasil dan analisis, kesimpulan dalam penelitian ini adalah: (1) Warna dalam menciptakan relaksasi sangat penting bagi responden dan kedua warna dingin dan warna hangat dapat membuat dan menciptakan relaksasi. (2) Hal-hal yang mempengaruhi pemilihan warna untuk meningkatkan bisnis hotel adalah tujuan untuk tinggal di hotel, pertimbangan ini untuk bekerja dan nilai pribadi seperti liburan, juga relaksasi.
\end{abstract}

Kata kunci : peran warna; relax; bisnis hotel

\begin{abstract}
[Title: Role of Color to Support The Achievement of Relaxation in Bussines Hotel (Case Studies of Business Hotel in Semarang)] Semarang as a business and tourism hub in Central Java provides an opportunity for investors to invest in Semarang. Lately the hospitality business in the city of Semarang show bright prospects. It can be seen from the increasing number of tourists who stay at the hotel. One reason is that many activities such as meetings held by government agencies, both local and national, held in the city of Semarang.Based on the results of the initial survey, most hotels in Semarang still minimal facilities and do not apply the importance of the implementation of color for visitors. Study about role of color to achieve relaxation is important because if the relaxation achieve so human can make more concentration and feel refresh. The aim of this study is: Study about how colors influence in creation of relaxation in business hotel in Semarang. The research sample is directed to the hotel using a cool color and a warm color hotel in Semarang. The method analysis used is descriptive analysis. Based on the result and analysis, the conclusion in this research are: (1) Thecolor in creating relaxation is very important for the respondent and both cool color and warm color can make and creating relaxation. (2)The things that affect the selection of colors to enhance the hotel business is for the purpose to stay in hotel, the consideration is for work and personal value such as holiday, also the relaxation.
\end{abstract}

Keywords : role of color; relaxation; business hotel

\section{Introduction}

Semarang city is the capital of the province of Central Java, Indonesia, as well as the fifth largest

\footnotetext{
${ }^{*}$ Penulis Korespondensi.

E-mail: barkasho@yahoo.com
}

metropolitan city in Indonesia after Jakarta, Surabaya, Bandung and Medan. As one of the most developed cities in Java, whether economic, trade, services, industry and tourism as well as being interland in Central Java. Semarang City can play a role in the international sphere. The more organized relations 


\section{Teknik, 36 (2), 2015, 86}

with other countries open up the opportunity for foreign tourists who are aiming to do business in investing in Semarang.

The development of increasingly rapid development in Semarang City can be seen from the slogan "Visit Central Java in 2013" and "Welcome Tourism Semarang" bring positive impact to the development of tourism. Many malls are the main attraction for tourists who will visit the city of Semarang. But behind the development of the tourism sector of the city of Semarang as historic buildings travel, family travel, culinary tourism, religious tourism and nature tourism.

Semarang as a business and tourism hub in Central Java provides an opportunity for investors to invest in Semarang. Lately the hospitality business in the city of Semarang show bright prospects. It can be seen from the increasing number of tourists who stay at the hotel. One reason is that many activities such as meetings held by government agencies, both local and national, held in the city of Semarang. In addition, other supporting factor is the increasing status of Ahmad Yani airport into an international airport, thus stimulating in the number of hotels in Semarang.

Based on data from the Indonesian Hotel and Restaurant Association (PHRI) there were 37 hotels in Semarang and all the star hotels average occupancy rate is high. Based on the initial survey, most hotels in Semarang still have minimal facilities and do not apply the importance of the implementation of color. This is the problem that interesting to be analyzes. Therefore it is important to conduct study in the role of color in Semarang.

Based on the background of the study above, so this research entitled: "Role of Color to Support the Achievement of Relaxation in Bussines Hotel (Case Studies in Semarang)".

\section{Basic Concept}

Hotel is a commercial establishment providing lodging, meals, and other guest services. In general, to be called a hotel, an establishment must have a minimum of six letting bed rooms at least three of which must have attached (ensuite) private bathroomfacilities. Although hotels areclassifiedinto 'Star' categories (1-Star to 5-Star), there is no standard method of assigning these ratings, and compliance with customary requirements is voluntary. A hotel with a certain rating, for example, is may look very different from another country hotel with the same rating, and would provide a different level of amenities, range of facilities, and quality of service. Whereas hotel chainsassure uniform standards throughout, non-chain hotels (even within the same country) may not agree on the same standards. Bussiness hotel is the three hotel that aimed to the consumers visit in budget hotel especially bussiness trip.

\subsection{Color}

Color is one of the variables that have been shown to induce a feeling of relaxation. Each of the three dimensions associated with the color has been shown to affect the feeling of relaxation. The dimensions of color, which is a dimension that has been the focus of both academic and industrial research (Bellizzi and Hite 1983; Gorn et al 2004; Jacobs et al 1974). That are two classification that are cool color and warm color (Rea, 1999, p.89).

The level of light or illumination falling on the surface can be measured in foot-candles or lux. A foot-candle (fc) is a unit of illumination equal to the amount of light falling on the surface within a radius of one foot from the source. The lux (lx) is an international system unit lighting unit and luminous emittance. It is used in photometry as a measure of the intensity of the light hitting or passing clear surface. This is analogous to the radiometric unit watts per square meter, but with the power at each wavelength weighted by the luminosity function, a standard model of human brightness perception (Winchip 2008, p.29).

\subsection{Warm and Cool Color}

The distinction between warm and cool colors has been important since at least the late 18 th century. It is generally not remarked in modern color science or colorimetry in reference to painting, but is still used in design practices today. The contrast, as traced by etymologies, seems related to the observed contrast in landscape light, between the "warm" colors associated with daylight or sunset and the "cool" colors associated with a gray or overcast day. Warm colors are often said to be hues from red through yellow, browns and tans included; cool colors are often said to be the hues from blue green through blue violet, most grays included. There is historical disagreement about the colors that anchor the polarity, but 19th-century sources put the peak contrast between red orange and greenish blue (Winchip 2008).

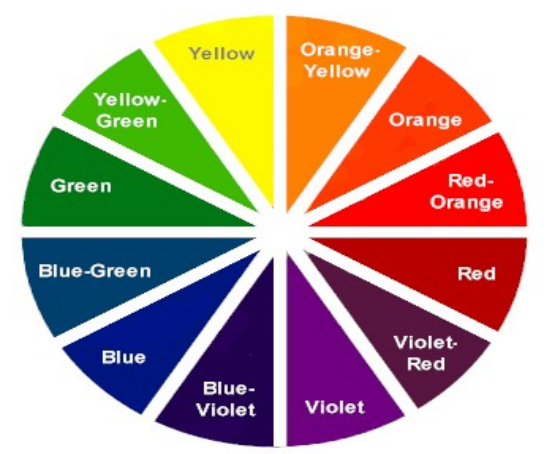

Figure 1. Color scheme (Winchip, 2008)

Color theory has described perceptual and psychological effects to this contrast. Warm colors are said to advance or appear more active in a painting, while cool colors tend to recede; used in interior design or fashion, warm colors are said to arouse or stimulate the viewer, while cool colors calm and relax. Most of these effects, to the extent they are real, can 


\section{Teknik, 36 (2), 2015, 87}

be attributed to the higher saturation and lighter value of warm pigments in contrast to cool pigments. Thus, brown is a dark, unsaturated warm color that few people think of as visually active or psychologically arousing. Contrast the traditional warm-cool association of color with the color temperature of a theoretical radiating black body, where the association of color with temperature is reversed. For instance, the hottest stars radiate blue light (i.e., with shorter wavelength and higher frequency) and the coolest radiate red (Winchip, 2008).

\subsection{Role of Color in Relaxation}

Color has psychologicaleffect based on the research on color, as such, has concentrated on color preference (Terwogt \& Hoeksma, 1995) or the relation between color and emotion or mood (Levy, 1984). Research on the relations between color and performance and color and mood has yielded mixed results. Knez (2001) found no main effects of the color of environmental light on mood or performance, Knez and Niedenthal (2008) found that performance in a video game was better when the game world was lit by warm (reddish) as opposed to cool (bluish) light. In Knez and Niedenthal's study the reddish light was rated as more pleasant, leading the authors to suggest that the difference in performance between the conditions may have been mediated by pleasantness.

Colors can relate to our emotions and feelings. The color blue is associated with comfort and security, orange is perceived asdistressing and upsetting, yellow as cheerful, purple as dignified (Ballast, 2002). The red color has positive and negative impressions such as active, strong, and passionate, but on the other hand aggressive, bloody, raging and intense. The green color has a retiring and relaxing effect. The green color also has positive and negative impressions such as quietness, naturalness, and conversely tiredness and guilt (Davey, 1998; Linton 1999). In a study examining color-emotion associations, Boyatzis and Varghese (1994) found that light colors (e.g., yellow, blue) are associatedwith positive emotions (e.g., happy, strong) and dark colors (e.g., black, gray) with negative emotions (e.g. sad, angry). Hemphill (1996) also found that bright colors elicited mainly positive emotional associations, while dark colors elicited negative emotional associations, confirming the results obtained by Boyatzis and Varghese (1994). However, Saito (1996) found that the color black elicited both negative and positive responses among Japanese subjects, and that black was often a preferred color among young people.

\section{Method}

\subsection{Research Approach}

Based on the formulation and purpose in this study, which is to formulate the concept of reason and the use of color in the interior of the hotel to create a feeling of relax, then this is the kind of research including qualitative research for the purpose of this research is to develop a theoretical outline of field conditions and illustrates the fact that complex about the concept and application of the use of color in the interior of the hotel to create a feeling of relax, and the factors that influence it.

Moleong (2007) suggested that qualitative methodology is a research procedure that produces descriptive data in the form of words written or spoken of people and observed behavior.Qualitative research has five kinds of characters, namely the researcher as the primary instrument went straight to the source of the data, the data collected tend to form words rather than numbers, researcher further emphasizethe process, not solely on the results, researchers conducted inductive analysis tends to express the meaning of situation observed, proximity researcher with the respondent is very important in the study.

\subsection{Population and Sample}

In the study sample selection technique used non-probability sampling is a technique that is not based on a statistical formula, but rather the subjective judgment by the researchers based on the range and depth of the problem under study. The characteristics of qualitative determination of the participants is the low number, non-representative, is determined based on the theory, and purposive. In qualitative research, the sampling procedure (Sarantakos, 1993).

In addition, participants taking these considerations are appropriate and represent the issues examined where in determining the sample to be studied based on the selection criteria for some samples that the object of the research is the hotel that uses color and warm color cool color in Semarang.

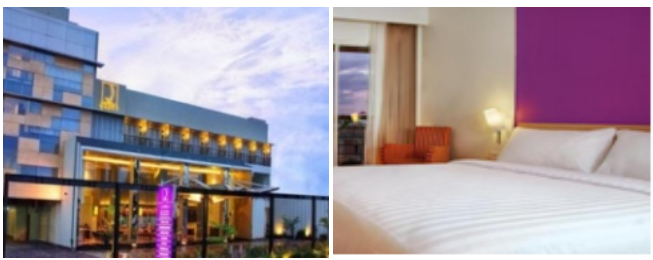

Figure 2. Quest Hotel (Field survey, 2015)

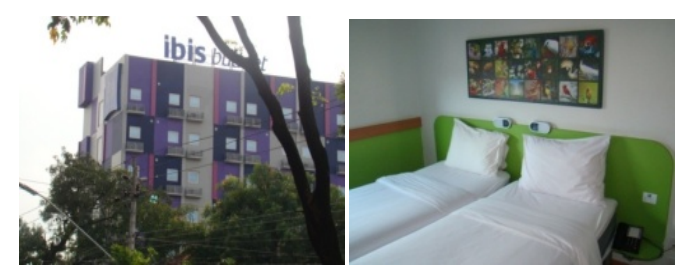

Figure 3. Ibis Budget Hotel (Field survey, 2015)

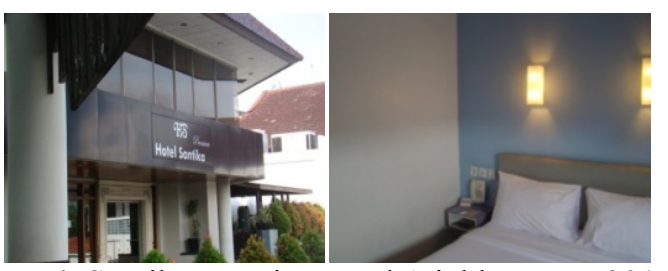

Figure 4. Santika Premier Hotel (Field survey, 2015) 


\section{Teknik, 36 (2), 2015, 88}

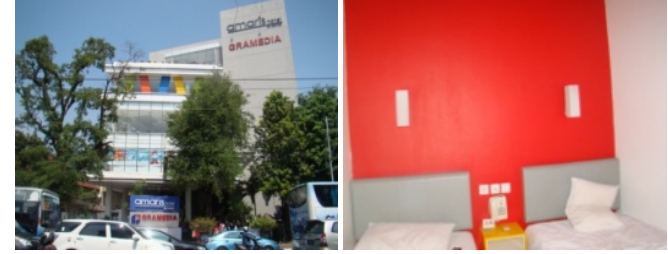

Figure 5. Amaris Hotel (Field survey, 2015)

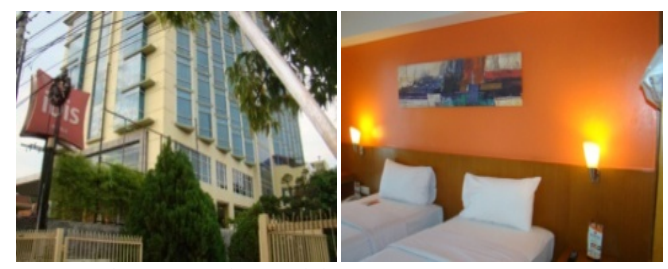

Figure 6. Ibis Hotel (Field survey, 2015)

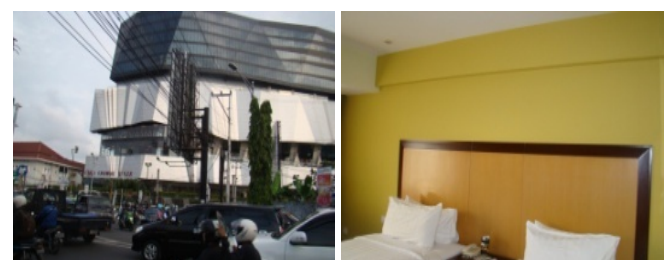

Figure 7. Crown Hotel (Field survey, 2015)

The descriptive analysis was used to describe the role of color in making relaxation deeply.

\section{Results and Discussion}

4.1. Factors affect the selection of colors to enhance the hotel business

The classification hotel for warm and cool colors that is 45 respondents willing to stay in the warm colos hotel and the another 45 respondent is stay in the cool colors hotel in Semarang. From the data, it can be seen that the purpose majority of the respondents to stay in the hotels is for holiday $(21 \%)$ and also because the project (work) that is $18 \%$ and meeting $17 \%$. After that for the wedding (14\%).

The consideration majority of the respondents to stay in this hotel is because the hotel is friendly $(29 \%)$ from the staff and service, also because it is relaxing $(22 \%)$. So it can be concluded that this hotel make the respondents feel relax, friendly and the good service quality, and these three things is the important things to be considered as the hotel manager to attract the customers in the future. The majority of the respondents feel relax to stay in this hotel $(74 \%)$. the majority of respondents that stay in cool colors hotel is more relax (36 respondents) rather than they who stay in warm hotel (31 respondents). But the differences is not so far so it can be say that cool colors and warm color can make relaxing for the respondents. Hotels with more color cool color classification gives the feeling of relax because it is based on the results of a questionnaire showed that more respondent to the needs of relax staying at the hotel with a cool color. This is because respondents are staying at the hotel for work purposes and in desperate need of feeling relaxe after doing the activity.

The cool color will make the room more bigger and also it does not make us to feel warm. The cool color reflect the sending colored light in a dark color when take a rest and make soul more comfortable. Mean while, the warm color can make feeling of warmth skew, intimate atmosphere, and relaxation. These warm colors are intense and can stimulate the viewers.

\subsection{The Role of Color in Creating Relaxation}

The second part in this section is to discuss about the role of color in creating relaxation for the hotel questionnairres. The causes majority of the respondents feel relax to stay in this hotel is because the color $(40 \%)$ and the service $(28 \%)$. Based on the data collection it can be say that the color play important role because when it is raining day, the color warm will make you more comfortable, and when it is hot the cool color will make you more comfort. Another is when they feel stressed, the cool color can make them more relax because the color is soft.

The majority of the respondents stated that the color use in this hotel make them relax $(68 \%)$. Based on the data collection also known that the role of color make relax because the color play important things to the human brain and can make more relaxing when we stressed. The respondents also say that the color make them relax because when they feel sad or distress and will be fell more relax when come in the room of hotel and see the ceiling and wall with warm or cool colors. Majority of the respondents stated that it is important to create the relaxation in a hotel $(72 \%)$. The majority of the respondents likes the green color $(26 \%)$ and blue $(22 \%)$ because the cool colour makes more relaxing rather than the warm color.

The distinction between 'warm' and 'cool' colors has been important since at least the late 18th century. It is generally not remarked in modern color science or colorimetry in reference to painting, but is still used in design practices today. The contrast, as traced by etymologies in the Oxford English Dictionary, seems related to the observed contrast in landscape light, between the "warm" colors associated with daylight or sunset and the "cool" colors associated with a gray or overcast day. Warm colors are often said to be hues from red through yellow, browns and tans included; cool colors are often said to be the hues from blue green through blue violet, most grays included. There is historical disagreement about the colors that anchor the polarity, but 19th-century sources put the peak contrast between red orange and greenish blue.

Color theory has described perceptual and psychological effects to this contrast. Warm colors are said to advance or appear more active in a painting, while cool colors tend to recede; used in interior design or fashion, warm colors are said to arouse or stimulate the viewer, while cool colors calm and relax. Most of these effects, to the extent they are real, can be attributed to the higher saturation and lighter value of warm pigments in contrast to cool pigments. Thus, brown is a dark, unsaturated warm color that few 


\section{Teknik, 36 (2), 2015, 89}

people think of as visually active or psychologically arousing.

Contrast the traditional warm-cool association of color with the color temperature of a theoretical radiating black body, where the association of color with temperature is reversed. For instance, the hottest stars radiate blue light (i.e., with shorter wavelength and higher frequency) and the coolest radiate red.

Cool colors such as blue, green and light purple have the ability to calm and soothe. Where warm colors remind us of heat and sunshine, cool colors remind us of water and sky. Unlike warm colors, cool colors look as though they recede, making them great for small rooms you want to look larger. If we have tiny bedroom or powder room that we want to visually enlarge try painting a color such as light blue to make it look more spacious.

The cool color, especially the blue side of the spectrum along with cool browns and grays and the cool off whites possess all of the qualities of coolness in that they are calming, focusing and soothing to our intellect, which craves a cooler atmosphere. These colors quiet the emotions and sharpen our thoughts, allowing our mind to do its best work. This is why the cool blues are the most popular color for business suits and shirts, as well as the hotel rooms also. Cool colors are therefore best in private rooms where concentration, calmness and rest are most important, such as the bedroom, office, and hotel rooms.

Meanwhile, the warm color give the impression of a cheerful, warm, happy, full of energy and uplifting. Especially in the rainy seasons, the warm color can give the warmth to the hotel visitors. Bright or warm colors can have positive effects, creating a sense of optimism, improve self-confidence, and describe expectations. The bright colors also stimulate the brain and make people more vigilant and assertive. Another psychological effect of warm color is give cheerfulness nature, ambition, and energetic. Usually the warm color related to security sensuality, pleasant demeanor, and triggers a person's appetite. Also illustrates familiarity, friendliness and comfort giver effect, bright colors which can have positive effects, creating a sense of optimism. So both the warm and cool color have each function and perception to make the hotel consumers feel comfort and relax.

\section{Conclusion}

From the discussion and analysis, the conclusion in this research as follows:

a. The majority of respondents that stay in cool colors hotel is more relax $(40 \%)$ rather than they who stay in warm hotel $(34.44 \%)$.

b. The majority of the respondents feel relax to stay in this hotel is because the color $(40 \%)$ and the service $(28 \%)$.

The recommendations are:

a. The management of bussiness hotel in Semarang should pay attention to the interior design and color because according to the result of this research that color play important role for the hotel's customers.

b. For the management hotel, should add the tourist guide for customers, training staff to speak english well, the restaurant should be add with international food menu, because majority only have Indonesian food, tourist information, alarm clock, health and fitness centre, green lighting energizers and service should be more active and know about the information, meeting in the airport, ATM machines or changing money.

c. In the future research can be added more variables that affecting the consumers attractiveness to stay in hotel.

\section{References}

Ballast, D. K. (2002). Interior design reference manual. Belmont, CA: Professional Pub.

Bellizzi, J.A., A.E. Crowley and R.W. Hasty. (1983). The Effects of Color in Store Design. Journal of Retailing, Vol. 59, No. 1: 21-45.

Boyatzis, C. J., and R. Varghese. (1994). Children's emotional associations with colors. Journal of Genetic Psychology, 155: 77-85.

Davey, P. (1998). True colors: The glorious polychromy of the past suggests a strong historical need for color, despite current reductive fashions. The Architectural Review, 204: 34-36.

Gorn, G.J., A. Chattopadhyay, J. Sengupta and S. Tripathi, (2004). "Waiting for the Web : How Screen Color Affects Time Perception," Journal of Marketing Research, Vol. 41, No. 2: 215-225.

Hemphill, M. (1996). A note on adults' color-emotion associations. Journal of Genetic Psychology, 157: 275-281.

Jacobs, Keith W. and Frank G. Hustmyer Jr. (1974), Effects of Four Psychological Primary Colors on GSR, Heart Rate, and Respiration Rate, Perceptual and Motor Skills, 38, 763-66.

Knez, I. (2001). Effects of colour of light on nonvisual psychological processes. Journal of Environmental Psychology, 21, 201-208.

Knez, I., \& Niedenthal, S. (2008). Lighting in digital game worlds: Effects on affect and play performance. Cyber Psychology\& Behavior, 11, 129-137.

Levy, B.I. (1984). Research into the psychologicalmeaning of color. American Journal of Art Therapy, 23, 58-62.

Linton, H. (1999). Color in architecture: Design methods for buildings, interiors and urban spaces. New York: McGraw Hill.

Terwogt, M.M., \& Hoeksma, J. B. (1995). Colors and emotions: Preferences and combinations. Journal of General Psychology, 122, 5-17.

Moleong, 2007. Metodologi Kualitatif Edisi Revisi. Bandung: PT Remaja Rosdakarya.

Rea, M. S. (Ed.). (1999). Lighting handbook (9th ed.). New York: IESNA. 


\section{Teknik, 36 (2), 2015, 90}

Saito, M. (1996). Comparative studies on color preference in Japan and other Asian regions, with special emphasis on the preference for white. Color Research and Application 21 (1): 35-49.
Sarantakos, S. (1993). Social research. Melbourne: Macmillan Education Australia.

Winchip, S. M. (2008). Fundamentals of Lighting, New York, NY: Fairchild Publishers. 